\title{
The Meaning of Qualisign, Sinsign, and Legisign of Gejog Lesung Art "Mukti Lestari" in Sewon Bantul
}

\author{
Muhammad Muslich Candra Nagara ${ }^{1^{*}}$ Ayu Niza Machfauzia ${ }^{1^{* *}}$ \\ ${ }^{1}$ Faculty of Language and Arts, Yogyakarta State University, Yogyakarta, Indonesia \\ ${ }^{*}$ Corresponding author. Email: muslichcandra@gmail.com \\ ${ }^{* *}$ Corresponding author. Email: niza.kudrat@gmail.com
}

\begin{abstract}
This research aims to reveal the meaning of signs in terms of qualisign, sinsign, and legisign, look for the process of sign changes, and reveal the norms of Gejog Lesung art, using Pierce's semiotic analysis. Data source is a phenomenon that exists in the Gejog Lesung art. The research instruments were interviews, documentation and observation. The results were (1) the Gejog Lesung art based on qualisign, means simple, traditional and popular, based on sinsign, means actualization of events, based on legisign, means prohibitions, orders, and appeals. (2) The process of changing the sign is trichotomically known as social dynamics into the society norm. (3) Norms that arise in the Gejog Lesung art are prohibitions, suggestions and appeals. So, the Gejog Lesung art contains meaning that can be used as a lesson by the community, with a more modern delivery so that it can be accepted by all people in facing the challenges of the Industrial Revolution 4.0.
\end{abstract}

\section{Keywords - Gejog Lesung, sign, semiotics}

\section{INTRODUCTION}

Some relevant research study was conducted by Mustikasari [1] and Suabe [2]. Mustikasari [1] found that there are symbols whose meanings describe God Balinese, Javanese and Hindu culture, namely Widi, Widi Tunggal, Hyang Widi, Hyang Suksma, Ida Hyang Widi, Tayasuksma, Mahapadma, Dewa, Hyang Triaagni, Sanghyang Titah, and symbols whose meanings describe truth, namely Misadya Ayu, Sanghyang Dharma, Hyang Dharma, dharma, Bathara Dharma, and Sang Dharma, all of which describe the teachings and noble character. While, the symbols of the concepts of Balinese, Javanese and Hindu culture teach about the obligation of religious people to praise and worship the Almighty God.

While Suabe [2] found that the historical meaning (historical) is as a literal meaning, while in the allegorical meaning, Kuri and Pasai themselves are figurative meanings. Kuri and Pasai themselves are considered people who have more power. Then, in the tropological meaning, four meanings are found, namely symbolic and diactical meanings and anagogical (mystical) meanings, spiritual or mystical visions as eternal truths.

Based on the description of the Gejog Lesung art, several problems were identified, including the public do not yet know the nature, philosophy, and the meaning of the norms of Gejog Lesung art, and the community was more interested in modern art. So, this research focuses on how the meaning of the sign dimensions in the ground (qualisign, sinsign, and legisign) of the Gejog Lesung art Mukti Lestari in Sewon Bantul. This is because researcher looks for sign meanings on the basis of the rules arising from the art process in the traditional art of Gejog Lesung.

So, the formulation of the problem in this research is "How is the meaning of the qualisign, sinsign, and legisign contained in the Gejog Lesung art Mukti Lestari in Sewon Bantul?". So, the traditional art of the Gejog Lesung Mukti Lestari in Sewon Bantul is an art that has a sign. The signs can be seen from several social rules such as merti dusun, gunungan, and rayahan. Every sign produced has a purpose, purpose, and meaning that are visible in plain view.

\section{THEORETICAL REVIEW}

\subsection{The Essence of Traditional Art}

Art is a part of culture. Art can be interpreted as things that are created and realized by humans, which can provide a sense of pleasure and satisfaction with the beautiful tastes [3].

While Shils [4] explains that tradition is everything that is passed down from the past to the present. This shows that all aspects of human life are inseparable from tradition, including the music art. A similar thing was stated by Alwi [5] that traditional arts were created by people who contain elements of beauty whose results belong together. Unlike the arts in general, traditional art is more regional in nature, where art is more representative of the state of a particular regional tradition and is passed down from one generation to the next generation, which includes customs, 
social systems, knowledge systems, languages, arts and belief systems.

\subsection{Gejog Lesung}

Gejog Lesung is one of the arts originating from the Java region. This art grows and develops in rural areas where the majority of the population lives as farmers. The synonym of lesung is long lumpang [6]. Lumpang is a tool for making flour and separating rice seeds with their outer skin (grain). While, the bat is called as alu.

Based on the sound, Gejog Lesung is a musical instrument whose sound source is from the instrument itself or "idiophone". The blow technique of lesung is also varies, to produce a unique rhythm lesung is beaten in a row. Gejog Lesung show is played by six people. The uniqueness of the Gejog Lesung show is the rhythm played by several players whose rhythm can actually be played by one person.

The term blow used in the Gejog Lesung show according to Moertjipto [6] is the first person's blow called gawe, the second person's blow called arang, the third person's blow is called kerep, the fourth person's blow is called umplung, the fifth person's blow is called nutu, and the sixth person's blow called dundung.

\subsection{Semiotics}

Semiotics is one of the sciences or methods of analysis to study sign, while signs are something that applies to something else [7] [8]. For example, a bird flying from the south indicates winter is coming, a white stick indicates blindness, arrows indicate directions.

Semiotics consists of at least nine types [9], namely analytic semiotics, descriptive semiotics, faunal semiotics, cultural semiotics, narrative semiotics, natural semiotics, normative semiotics, social semiotics, social semiotics and structural semiotics. While the number of applied semiotic fields is recorded in 19 fields which can be considered as semiotic scientific study material [10], namely (1) animal semiotics, (2) smell sign, (3) groping communication, (4) taste codes, (5) paralinguistic, (6) medical semiotics, (7) kinesik and prosemik, (8) music codes, (9) formalized languages, (10) written languages, alphabet, secret codes (11) ) natural languages, (12) visual communication, (13) object systems, (14) flow structures, (15) text theory, (16) cultural codes, (17) aesthetic texts, (18) mass communication, and (19) rhetoric.

The signs according to Charles Sander Peirce [11] are "something that represents something". More specifically, it can be said that something represented is human experience both physical experience and mental experience. Classification of marks can be done in three ways, namely; signs produced by nature, signs produced by animals, and signs produced by humans [9].

From some semiotic experts, Charles Sanders Peirce (America) is one of the figures who gave rise to modern semioticism, namely the Anglo-Saxon Semiotics. Semiotic for Peirce is an action, influence or cooperation of three subjects namely; sign, object, and interpretant. The sign model proposed by Peirce is closely related to the basic principle of a representative sign, that is, a sign that represents something else. The process of sign meaning in the Peirce model follows the elemental relationship between the three sign dimensions, namely represent ament (R) - object (O) - interpretant (I). Meanwhile, Christomy \& Yuwono [12] and Pateda [9] add that the analysis of Peirce's semiotic sign is divided into three characteristics of ground, namely qualisign, sinsign, and legisign. The explanation of the relationship analysis based on the represent ament can be clarified in Figure 1 as follows:

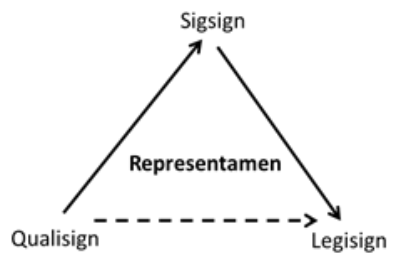

Figure 1. Classification of Sign Relationship Based on Representament

Qualisign is something that uses representation in the form of quality and has the quality to be a sign. This type of sign cannot function as a sign until it is formed as a sign, for example harsh words, weak, gentle, and melodious. Sinsign is the actual existence of objects or events that exist on signs that have been formed and can be considered as represent ament, but have not functioned as signs, such as fuzzy or murky words that exist in the description of turbid water river that indicate there is rain in the headwaters or red color which takes form from itself or takes a certain form outside of self. While legisign is norms contained by signs, for example traffic signs that contain things that may or may not be carried out by humans, for example the red color on traffic lights on the highway which becomes the norm or rules for motorcyclists to stop and have been agreed by the community.

\section{METHODS}

This research used a qualitative method with a pragmatic semiotic analysis with a descriptive interpretative textual approach, in which the researcher interpreted the results of the research into the meaning of changing Gejog Lesung's meaning into a norm order found in the traditional art of Gejog Lesung Mukti Lestari in Sewon, Bantul. In the process of the research, the researcher focused himself on the subjective meaning, definition, metaphor, and description of specific cases [13] with the type of semiotic analysis of Charles Sanders Peirce.

This research was conducted in the Mukti Lestari community Sewon Bantul, because in that area the Gejog Lesung art was still actively performed during celebrations, such as the celebration of the merti dusun. Besides that, the people in this hamlet were very enthusiastic about Gejog Lesung's art activities. So, the subjects in this research consisted of several people, including Mr. Nasro, as the founding figure of the Gejog Lesung art Mukti Lestari, the player of the Gejog Lesung art Mukti Lestari y, 
and the people living around the Mukti Lestari Sewon Bantul.

In the process of collecting data, researcher went directly to the field to gather a number of information needed. This research used three kinds of data collection techniques, namely observation, interviews, and documentation. After the data was collected, Pierce's semiotic data was analyzed by Pierce's semiotic to find the meaning contained in the Gejog Lesung art Mukti Lestari. In addition, researches also carried out several stages in analyzing data, namely reducing data by summarizing, choosing the main things, focusing on important things, looking for themes and patterns.

Next, the researcher presented the data obtained in the form of brief descriptions, charts, relationships between categories, flowcharts, and the like. Then the researcher carried out the analysis by interpreting the signs tirkotomi based on a semiotic ground. The analysis step was by classifying the marks based on qualisign, sinsign, and legisign. The next step was drawing conclusions supported by valid and consistent evidence. Furthermore, researcher increased the validity of the data obtained so that it was truly in accordance with the aims and objectives of the research. Meanwhile, the validity was done in several ways, namely perseverance of the district, triangulation.

\section{FINDING AND DISCUSSION}

Gejog Lesung art Mukti Lestari is an art that promotes traditional art and is based in Krandohan, Pendowoharjo, Sewon, Bantul. The Mukti Lestari Community was founded on the initiative of Mr. Nasro on November 15, 1996. The aim of establishing Mukti Lestari community was to revive the arts of the local area, specifically the Gejog Lesung art. Gejog Lesung art consists of two groups of players, namely the group of woman and group of children, where each group consists of 6 players. Each group was accompanied by 10 to 12 dancers and one singer.

Gejog Lesung art Mukti Lestari raises traditional songs and religious songs. Some examples of songs that are often played include Berantas Narkoba, Campur Manis, Cancut Gumeregut, Caping Gunung, E Nginang Karo Ngilo, Geblek Wates, Geplak Bantul, Gethuk, Autumn Mountain, Kangen, Lesung Jumenglung, Lesung Manis, Lir -Ilir, Molimo, Ngidam Sari, Sailboat, PKK Maju, Projotamansari, Sholawat Badar, Tombo Ati, Yaa Rasulalah, and Special Yogya. Gejog Lesung art Mukti Lestari once performed a performance at Sermo Reservoir Gelagah Indah, and Gedung Agung Yogyakarta. Gejog Lesung art had an active role in providing entertainment in the village of Krandohan in the event to commemorate the Independence Day of the Indonesia, Merti Dusun, Kartini Day and others.

\subsection{Signs that Appear Qualisign, Sinsign, and Legisign in the Gejog Lesung Art "Mukti Lestari” Kradohan Sewon Bantul}

Qualisign found in the traditional art of Gejog Lesung Mukti Lestari Krandohan Sewon Bantul was described in Table 1, as follows:

Table 1 Qualisign

\begin{tabular}{|c|c|c|}
\hline No & Sign & Qualisign \\
\hline 1 & Gejog Lesung & $\begin{array}{l}\text { 1. Graceful } \\
\text { 2. Proud } \\
\text { 3. Beautiful } \\
\text { 4. Unified } \\
\text { 5. Melodious (The sound of Gejog } \\
\text { Lesung) } \\
\text { 6. festive } \\
\text { 7. Loud } \\
\text { 8. Crowded } \\
\text { 9. uniforms } \\
\text { 10. Traditional } \\
\text { 11. Old }\end{array}$ \\
\hline 2 & Song & $\begin{array}{l}\text { 12. Good } \\
\text { 13. Moral } \\
\text { 14. Enthusiastic } \\
\text { 15. Beautiful } \\
\text { 16. Creative } \\
\text { 17. Educate } \\
\text { 18. Positive } \\
\text { 19. Religious } \\
\text { 20. traditional }\end{array}$ \\
\hline 3 & Bowo & $\begin{array}{ll}\text { 1. } & \text { Good } \\
\text { 2. } & \text { Moral } \\
\text { 3. } & \text { Enthusiastic } \\
\text { 4. } & \text { Beautiful } \\
\text { 5. } & \text { Creative } \\
\text { 6. } & \text { Educate } \\
\text { 7. } & \text { Positive } \\
\text { 8. } & \text { Religious } \\
\text { 9. } & \text { traditional } \\
\end{array}$ \\
\hline 4 & Clothing & $\begin{array}{ll}\text { 1. } & \text { Beautiful } \\
\text { 2. } & \text { Neat } \\
\text { 3. } & \text { Simple } \\
\text { 4. } & \text { Uniform } \\
\text { 5. } & \text { Traditional } \\
\end{array}$ \\
\hline 5 & Merti dusun & $\begin{array}{ll}\text { 1. } & \text { Enthusiastic } \\
\text { 2. } & \text { A lot } \\
\text { 3. } & \text { Beautiful } \\
\text { 4. } & \text { Unified } \\
\text { 5. } & \text { Creative } \\
\text { 6. } & \text { Fun } \\
\text { 7. } & \text { Festive } \\
\text { 8. } & \text { Crowded } \\
\text { 9. } & \text { Simple } \\
\text { 10. } & \text { Amazed } \\
\text { 11. } & \text { Traditional } \\
\end{array}$ \\
\hline 6 & Gunungan & $\begin{array}{ll}\text { 1. } & \text { Impressive } \\
\text { 2. } & \text { Generous } \\
\text { 3. } & \text { Beautiful } \\
\text { 4. } & \text { Unified } \\
\text { 5. } & \text { Simple } \\
\text { 6. } & \text { Amazed } \\
\text { 7. } & \text { Height } \\
\end{array}$ \\
\hline 7 & Rayahan & $\begin{array}{ll}\text { 1. } & \text { Enthusiastic } \\
\text { 2. } & \text { Young } \\
\text { 3. } & \text { Crowded } \\
\text { 4. } & \text { Routine } \\
\text { 5. } & \text { Happy } \\
\text { 6. } & \text { Old } \\
\end{array}$ \\
\hline
\end{tabular}


Sinsign found in the traditional art of Gejog Lesung Mukti Lestari Krandohan Sewon Bantul was described in Table 2, as follows:

Table 2 Sinsign

\begin{tabular}{|c|c|c|}
\hline No & Sign & Sinsign \\
\hline 1 & Gejog Lesung & $\begin{array}{ll}\text { 1. } & \text { Come in } \\
\text { 2. } & \text { Gather together } \\
\text { 3. } & \text { Listen } \\
\text { 4. } & \text { Blow } \\
\text { 5. See } \\
\text { 6. Invite } \\
\text { 7. } \text { Random } \\
\text { 8. } \text { Call } \\
\text { 9. Everlasting } \\
\text { 10. Work } \\
\text { 11. Educate } \\
\text { 12. Teach } \\
\text { 13. Embed } \\
\text { 14. Make use of } \\
\text { 15. Tour } \\
\text { 16. Announce }\end{array}$ \\
\hline 2 & Song & $\begin{array}{ll}\text { 1. } & \text { Threaten } \\
\text { 2. } & \text { Invite } \\
\text { 3. } & \text { Prohibit } \\
\text { 4. } & \text { Listen up } \\
\text { 5. } & \text { Come in } \\
\text { 6. } & \text { Share } \\
\text { 7. } & \text { Preserve } \\
\text { 8. } & \text { Suggest } \\
\text { 9. } & \text { Directing } \\
\text { 10. } & \text { Guiding } \\
\text { 11. } & \text { Welcoming } \\
\text { 12. } & \text { Delivering } \\
\text { 13. } & \text { Introducing } \\
\text { 14. } & \text { Announce } \\
\text { 15. } & \text { Pray } \\
\text { 16. } & \text { Inform } \\
\end{array}$ \\
\hline 3 & Bowo & $\begin{array}{l}\text { 1. Threaten } \\
\text { 2. Invite } \\
\text { 3. Prohibit } \\
\text { 4. Listen up } \\
\text { 5. Come in } \\
\text { 6. Share } \\
\text { 7. Preserve } \\
\text { 8. Suggest } \\
\text { 9. Directing } \\
\text { 10. Guiding } \\
\text { 11. Welcoming } \\
\text { 12. Delivering } \\
\text { 13. Introducing } \\
\text { 14. Announce } \\
\text { 15. Pray } \\
\text { 16. Inform } \\
\text { 17. Appeals } \\
\end{array}$ \\
\hline 4 & Clothing & $\begin{array}{ll}\text { 1. } & \text { Honorable } \\
\text { 2. } & \text { Coloring } \\
\text { 3. } & \text { Explaining } \\
\text { 4. } & \text { Introducing } \\
\text { 5. } & \text { Awake } \\
\end{array}$ \\
\hline 5 & Merti dusun & $\begin{array}{l}\text { 1. Come in } \\
\text { 2. Gather together } \\
\text { 3. Look } \\
\text { 4. Take it } \\
\text { 5. Invite } \\
\text { 6. Call } \\
\text { 7. Conquer } \\
\text { 8. Work } \\
\text { 9. Travel } \\
\text { 10. Announce }\end{array}$ \\
\hline
\end{tabular}

\begin{tabular}{|c|c|c|}
\hline & & $\begin{array}{l}\text { 11. Asking } \\
\text { 12. Seeing } \\
\text { 13. Bring in } \\
\text { 14. Welcoming }\end{array}$ \\
\hline 6 & Gunungan & $\begin{array}{ll}\text { 1. } & \text { Lift } \\
\text { 2. } & \text { Parading } \\
\text { 3. } & \text { Build } \\
\text { 4. } & \text { Invite } \\
\text { 5. } & \text { Calling } \\
\text { 6. } & \text { Preserve } \\
\text { 7. } & \text { Seeing } \\
\text { 8. } & \text { Stringing up } \\
\text { 9. } & \text { Directing } \\
\text { 10. } & \text { Bring in }\end{array}$ \\
\hline 7 & Rayahan & $\begin{array}{ll}\text { 1. } & \text { Helping } \\
\text { 2. } & \text { Divide } \\
\text { 3. } & \text { Seize } \\
\text { 4. } & \text { Trying } \\
\text { 5. } & \text { Crowded } \\
\text { 6. } & \text { Bring in } \\
\text { 7. } & \text { Fighting } \\
\text { 8. } & \text { Gather } \\
\text { 9. } & \text { Sacrifice }\end{array}$ \\
\hline
\end{tabular}

Legisign found in the traditional art of Gejog Lesung Mukti Lestari Krandohan Sewon Bantul was described in Table 3, as follows:

Table 3 Legisign

\begin{tabular}{|c|c|c|}
\hline No & Sign & Legisign \\
\hline 1 & Gejog Lesung & $\begin{array}{ll}\text { 1. } & \text { Lesung Manis } \\
\text { 2. } & \text { Perahu Layar } \\
\text { 3. } & \text { Gending kodhok ngorek } \\
\text { 4. } & \text { Gending Jaran Pengkal } \\
\text { 5. } & \text { Gending Gejog Loro }\end{array}$ \\
\hline 2 & Song & $\begin{array}{ll}\text { 1. } & \text { Javanese Songs } \\
\text { 2. } & \text { Berantas Narkoba Song } \\
\text { 3. } & \text { Islamic Songs }\end{array}$ \\
\hline 3 & Bowo & $\begin{array}{l}\text { 1. Moral Message } \\
\text { 2. Played at the beginning }\end{array}$ \\
\hline 4 & Clothing & $\begin{array}{ll}\text { 1. } & \text { Neat } \\
\text { 2. } & \text { Polite } \\
\text { 3. } & \text { Closed } \\
\text { 4. } & \text { Uniforms } \\
\text { 5. } & \text { Clean } \\
\end{array}$ \\
\hline 5 & Merti dusun & $\begin{array}{ll}\text { 1. } & \text { Recitation } \\
\text { 2. } & \text { Prayer } \\
\text { 3. } & \text { Going around the village }\end{array}$ \\
\hline 6 & Gunungan & $\begin{array}{ll}\text { 1. } & \text { Conical upwards } \\
\text { 2. } & \text { Contains agricultural products }\end{array}$ \\
\hline 7 & Rayahan & $\begin{array}{ll}\text { 1. } & \text { Waiting } \\
\text { 2. } & \text { Unison } \\
\text { 3. } & \text { At the end }\end{array}$ \\
\hline
\end{tabular}

\subsection{The process of changing the meaning of the sign contained in the Gejog Lesung art "Mukti Lestari" Krandohan Sewon Bantul}

\subsubsection{Gejog Lesung}

The signification process produced by Gejog Lesung was based on the actualization of the events that occur and the signs that contained the norm. The sign which was interpreted based on the norm was Lesung Manis. Lesung Manis was a sign of the Gejog Lesung performance which 
started the show with the rules of the dancers started walking into the stage

\subsubsection{Song}

The process of changing the meaning of the song contained in the art of Gejog Lesung Mukti Lestari which was always brought is a Lesung Manis. This song told about the Gejog Lesung art which had existed since time immemorial. The process of changing the songs was based on the choice of songs including good, moral, uplifting, beautiful, educating, positive, religious and traditional.

\subsubsection{Bowo}

Bowo was a series of Gejog Lesung art which was sung in the beginning of a Lesung blow. It aimed to make society better, moral, positive, religious and traditional. This characteristic was reflected through the actualization of events. The community became aware of good things through invitations, prohibitions, and suggestions. With the existence of a bowo, the community also understood better about social norms.

\subsubsection{Clothing}

The clothing used by performers and dancers of the Gejog Lesung art Mukti Lestari was Javanese traditional clothing. The process of changing the meaning of clothes contained in the Gejog Lesung Mukti Lestari in nature that was beautiful, neat, simple art, uniform, traditional, beautiful. These characteristics were actualized by the way the wearers of traditional clothing behave noble, simple, and respectable.

\subsubsection{Merti Dusun}

The process of changing the meaning of Merti Dusun activities based on the nature of the sign produced a meaningful term, namely crowded, compact, beautiful, lively, amazed, lively and traditional. The nature of the sign made the community come, gather, welcome, and see the Merti Dusun activities. In the nature and actualization of signs produced indirectly, the Merti Dusun contains signs in the form of religious norms and social norms.

\subsubsection{Gunungan}

The Gunungan used in the process of Merti Dusun were based on staple foods from the results of local communities which were arranged to resemble the shape of a mountain. This Gunungan contains all agricultural products consisting of rice, sweet potatoes, coconut, eggplants, corn, long beans, sapodilla, guava, and chili. All were orderly that were made with a height of about 1.5 meters which were then paraded around the village.

\subsubsection{Rayahan}

Rayahan was intended to share happiness so that people can purify themselves physically and mentally. This meaning contained hidden messages, and noble values that not only function as regulators between individuals in society, but also organized human relationships with the natural environment, especially to the Creator.

\subsection{The norm contained in the Gejog Lesung art "Mukti Lestari" Krandohan Sewon Bantul}

\subsubsection{Gejog Lesung}

The Gejog Lesung performance contained the norm of politeness that was seen when the Lesung performers greet by dancing while bowing in front of the audience. The simple actualization of events was the norm that indirectly taught the public about hospitality to guests.

\subsubsection{Song}

The song Berantas Narkoba contained legal norms in the form of a ban on the use of illegal drugs. The song Tombo Ati, Yaa Rasulullah, and Sholawat Badar contained several religious norms. The religious norms were according to the contents of the song. For example, almost all players use head covers, which meant this was an obligation for adult women to use veil or cover her head.

\subsubsection{Clothing}

Javanese traditional clothing used by the players of Gejog Lesung contained habits and politeness in dressing beautifully and neatly. The use of traditional clothing was also an effort to love the local culture which was a reflection of noble culture.

\subsubsection{Merti Dusun}

The norms contained in Merti Dusun activities were customs and religious norms. This can be seen from the event that the community around the village paraded the harvest as an expression of gratitude.

\subsubsection{Gunungan}

Gunungan was made to symbolize the gratitude of the people towards Dewi Sri or the goddess of fertility for the abundant harvest.

\subsubsection{Rayahan}

Rayahan was conducted by the general public around the Krandohan region as a form of gratitude. According to information, Rayahan means who got the harvested mountains, they will have enough in food.

\section{CONCLUSIONS AND SUGGESTIONS}

Based on the analysis of signification in terms of qualisign, sinsign, and legisign contained in the Gejog Lesung art Mukti Lestari Krandohan Sewon Bantul, several conclusions are obtained. First, the Gejog Lesung art can be used as a means of instilling moral values and nonformal educational facilities. That is because Gejog Lesung has so many meanings contained in it, such as commands, prohibitions, warnings, and appeals.

The results of this study are expected to help the community in general in understanding the signs contained in everyday life, because if people do not understand the signs contained in everyday life, they will certainly be very detrimental to themselves and others in socializing. 


\section{ACKNOWLEDGMent}

I would first like to thank my colleagues who helped me to revise this article. They helped me to correct my writing errors. Lastly, I would like to give special acknowledgment to Dr. Ayu Niza Machfauziah M.Pd. as my thesis supervisor who supported me to finish this article. Her caring and spirit of open-minded has been such of inspiration and guidance for me.

\section{REFERENCES}

[1] Mustikasari, Dian. "Serat Dharma Sasana dalam Kajian Semiotik [Literature of Serat Dharma Sasana in semiotic studies]." Diss. Universitas Negeri Semarang, 2011. URL: https://ib.unnesa.ac.id/3569/

[2] R. S. Suabe, "Mitos Kuri dan Pasai dalam Etnik Wamesa: Kajian Semiotik [Myth of Kuri and Pasai in ethnic Wamesa: semiotic study]." unpublished.

[3] Djelantik, Anak Agung Made, Taufik Rahzen, and Ni Nyoman Manik Suryani. "Estetika: sebuah pengantar [Aesthetics: An Introduction]." Masyarakat Seni Pertunjukan Indonesia, 1999.

[4] Shils, Edward. Tradition. University of Chicago Press, 1981.

[5] Alwi, Hasan. "Kamus besar bahasa Indonesia [Great Dictionary of Bahasa Indonesia]." Jakarta: Balai Pustaka (2007).

[6] Moertjipto et al. "Bentuk-bentuk peralatan hiburan dan kesenian tradisional Daerah Istimewa Yogyakarta [Forms of traditional entertainment and arts equipment of Yogyakarta Special region]." Departemen Pendidikan dan Kebudayaan, Direktorat Jenderal Kebudayaan, Direktorat Sejarah dan Nilai Tradisional, Proyek Inventarisasi dan Pembinaan Nilai-Nilai Budaya, 1990.

[7] Berger, Arthur Asa. "Pengantar Semiotika: Tandatanda dalam Kebudayaan Kontemporer [Introduction to Semiotics: Signs in contemporary culture]." Tiara Wacana, 2010.

[8] Danesi, Marcel. "Pesan, tanda, dan makna [Messages, marks, and meanings]." Yogyakarta: Jalasutra (2010).

[9] Mansoer, Pateda. "Semantik Leksikal [Lexical semantics]." Jakarta: Rineka Cipta (2001).

[10] Eco, Umberto. A theory of semiotics. Indiana University Press, 1976.

[11] Benny, Hoed J. "Semiotik \& Dinamika Sosial Budaya [Semiotic \& the dynamics of social culture]." (2014).
[12] Christomy, Tommy, and Untung Yuwono. "Semiotika budaya. Pusat Penelitian Kemasyarakatan dan Budaya [Semiotics of Culture. Social and Cultural Research Center]." Direktorat Riset dan Pengabdian Masyarakat, Universitas Indonesia, 2004.

[13] Newman, William Lawrence. Social research methods: Qualitative and quantitative approaches. Allyn and Bacon, 1991. 